\title{
In the Backyard at Burcroft: Henry Moore's Experiments in Lead
}

\section{Rowan Bailey}

In the year 1935, Henry Moore and his wife Irina moved to a bungalow called Burcroft in the village of Kingston, near Canterbury in Kent, England. The house came with five acres of land, thus allowing Moore to further pursue his experiments in stone carving and lead casting. With Bernard Meadows as assistant, from 1936 to 1939, many lead pieces were produced. ${ }^{1}$ These early works embody the archetypes of Moore's practice: from the standing and reclining figures, first developed in the early 1930s, to the stringed figures of 1937 onwards, through to the interior figures and helmets of $1939-40$ that led to a later series of editions produced in the early 1950 and 1960s. During the decade of the 1930s Moore acquired great skill and aptitude for working with a variety of materials. Not only did he cultivate a special relationship to the textures and gradients of quarried stone and wood, he also perfected the technical processes of casting with the use of cheap materials (such as concrete and lead), and usually in make-shift/DIY environments. ${ }^{2}$ The low melting point of lead allows the material to be handled in simple domestic set-ups.

The mid to late 1930s also marks a moment at which Moore's sculptures start to gain visibility in group shows, both at home and abroad, including the United States. Moore was

\footnotetext{
${ }^{1}$ At that time Meadows was a student studying painting at the Royal College of Art in London and would spend the breaks living at Burcroft. For an account of Moore's time at Burcroft and Meadows' role as assistant see Roger Berthoud, The Life of Henry Moore (London: E. P. Dutton, 1987).

2 For a brief account of Moore's early experiments with concrete, see Rowan Bailey 'Concrete Thinking for Sculpture' parallax, 21:3, 241-250.
} 
heavily influenced by the avant-garde practices of European modernism in the early twentieth century, including Cubism, Surrealism and Constructivism. His active participation in international group exhibitions reveals allegiances, affinities and contributions to avantgardist ideas and principles. This was a time when the political climate in Europe was rapidly changing, the concerns of which were addressed in the curatorial strategies and mechanisms deployed by directors such as Alfred H. Barr, who became the head of the Museum of Modern Art (MOMA), New York, in 1929. In 1936, several of Moore's works featured in MOMA's Cubism and Abstract Art (curated by Barr), The International Surrealist Exhibition at the New Burlington Galleries (re-hung literally at the last minute at the demanding request of André Breton) and at the end of that year, MOMA's Fantastic Art, Dada, Surrealism (curated by Barr and which Breton withdrew from). Moore also had strong connections with projects such as Unit One and Circle - International Survey of Constructive Art and was positively endorsed by writers such as Herbert Read, whose consideration of his work on the international scene of modern art played a key role in shaping discursive understandings of his sculptural intentions and tendencies. ${ }^{3}$ This is not to neglect Moore's own writings in the 1930s, where ideas about the interrelations between form and material are articulated and expressed. His 'Statement for Unit One', of 1934 and 'The Sculptor Speaks', first published in 1937, are particularly fine examples of his sculptural thinking. ${ }^{4}$ In this respect, there is much to consider in a reading of Moore's early lead works.

\footnotetext{
${ }^{3}$ At the time Herbert Read was publishing works directly associated with the projects Moore was involved in, and had already written and published the first account of Moore as a sculptor in 1936. See in particular, Herbert Read, Henry Moore; Sculptor: An Appreciation (London: Zwemmer, 1934), Herbert Read (ed.). Unit One: The Modern Movement in English Architecture, Painting and Sculpture (London: Casel \& Co, 1934) and Hebert Read (ed.) Surrealism (London: Faber \& Faber, 1936).

${ }^{4}$ See Henry Moore, 'Statement for Unit One' in Read, Unit One: The Modern Movement in English Architecture, Painting and Sculpture, 29-30 and Henry Moore, 'The Sculptor Speaks',
} 
This chapter considers Moore's early experiments in lead in the artistic and cultural contexts of the inter-war period in Europe, between 1930 and 1939. It proposes to firstly, present the technical processes involved in casting lead, including some of the material relations at work in the archetypal forms that make up Moore's oeuvre, and within the makeshift making space at Burcroft, before secondly, situating some of these lead pieces within key exhibitions of the inter-war period, particularly those that served as important counterformations to the growth of fascism and its aesthetic ideologies.

\section{Lead Works Produced Between 1930-1939}

In the decade of the 1930s Moore was developing a rich and broad portfolio of works in lead, concrete, stone, marble and wood, alongside his drawings. There are twenty-five lead works listed from this period, with approximately twenty produced between 1938 and 1939. The works include (in chronological order): Seated Figure (1930, LH81, destroyed), Reclining Figure (1931, LH101), Mother and Child (1938, LH186), Reclining Figure (1938, LH193), Stringed Figure (1938, LH186e), Stringed Mother and Child (1938, LH186f), Reclining Figure (1938, LH192), Recumbent Figure (1938, LH184), Mother and Child (1939, LH200), Head (1939, LH195), Stringed Ball (1939, LH198), Stringed Figure (1939, LH199), Mother and Child (1939, LH201), Reclining Figure (1939, LH202), Reclining Figure: Blanket (1939, LH203), Reclining Figure (1939, LH204), Stringed Figure (1939, LH206), Stringed Figure (1939, LH207), Reclining Figure (1939, LH208), Reclining Figure: Snake (1939-40, LH208a), Figure (1939, LH209), Three Points (1939-40, LH211), The Helmet (1939-40, LH211), Interior Figure (1939- 
40, LH212a), The Bride (1939-40, LH213). ${ }^{5}$ In this period, Moore also created approximately twenty-three bronze works, but spread over a decade. Only one or two bronze pieces were produced each year; an indication of the possible expense and/or preoccupation with other materials such as stone or wood. ${ }^{6}$ In 1938-39, the busiest years of lead casting for Moore and Meadows, a total number of sixteen pieces were cast. Of the types of work produced, the reclining figures and the stringed figures are possibly the most distinct form-ideas generated, save for the later interior figures for The Helmet (1939-40), and a most unusual work called Three Points, cast in lead in 1939-40. Moreover, as his catalogue shows, Moore's encounters with lead certainly came into play long before his move to Burcroft in 1935 . One of the earliest pieces, appearing in the early group shows of the mid-1930s, was Reclining Figure of 1931 (LH101), a small lead torso, with a well-defined rib-cage. In 1961 Moore produced six editions of this figure in bronze. It is probable that he made the lead version in London, along with two other pieces, Mask of 1929 and Seated Figure of 1930 (since destroyed). His marriage to Irina in 1930 led to their move to Hampstead and a new studio environment. ${ }^{7}$ According to the sculptor conservators, Lyndsey Morgan and Rozemarin van der Molen, Moore made lead casts in the kitchen of their flat at Parkhill Road, between 1929 and $1931 .{ }^{8}$ But for the art

\footnotetext{
${ }^{5}$ See Henry Moore Foundation online catalogue of Henry Moore's works from 1914 to 1949 available at http://catalogue.henry-moore.org/collections

${ }^{6}$ The variants in stone and wood that Moore used are immense. In the works produced between 1930 and 1939, the following types of aggregate were used: Ham Hill stone, alabaster, Cumberland alabaster, Green Horton stone, ironstone, slate, Corsehill stone, Green stone, ebony, Burgundy stone, anhydrite stone, veined alabaster, verde di Prato, travertine marble, Armenian marble, African wonderstone, lignum vitae, Blue Horton stone, Corsham stone, white marble, birds eye marble, blue ancaster, travertine marble. The types of wood Moore used during this period include: elmwood, boxwood, cherry wood, beech wood, sycamore wood, dark African wood, Hopton Wood, walnut wood, yew wood, Pynkado wood. ${ }^{7}$ Prior to this, from 1924 onwards, Moore had been at Grove Studios in Hammersmith.

${ }^{8}$ See Lyndsey Morgan and Rozemarin van der Molen, 'Henry Moore's Approach to Bronze', in Henry Moore; Sculptural Process and Public Identity. Tate Research Publication, 2015. https://www.tate.org.uk/art/research-publications/henry-moore/lyndsey-morgan-and-
} 
historian Alice Correia, it may be that these early pieces were cast in professional London based foundries such as Gaskin's (Art Bronze Foundry) or Fiorini. ${ }^{9}$ Whether used in the 1930s or later on in the 1940s and 1950s remains to be seen, but one thing is certain: lead was a key ingredient in a broad and varied experimental phase in Moore's practice at the early stages of his career.

\section{Experiments in Lead at Burcroft}

Bernard Meadows provides many in-depth accounts of the lead casting process and his time at Burcroft with Moore. Several interviews undertaken by the Tate, the British Library's National Life Stories: Artists' Lives project and of course, the Henry Moore Foundation, shed light on the make-shift domestic set up, including what one can imagine was great patience on Irina's part as they used the bungalow's primus stove, cooking pots and pans, to melt the lead. ${ }^{10}$ Interestingly, one of the more detailed written accounts of lead made by Meadows

rozemarijn-van-der-molen-henry-moores-approach-to-bronze-r1151468(accessed 04 August 2018)

${ }^{9}$ See Alice Correia, 'Recumbent Figure 1938 by Henry Moore OM, CH', catalogue entry. January 2013, in Henry Moore: Sculptural Process and Public Identity. Tate Research Publication, 2015, https://www.tate.org.uk/art/research-publications/henry-moore/henrymoore-om-ch-recumbent-figure-r1147451 (accessed 21 August 2018).

The Henry Moore Foundation records do not appear to list these early works as having been cast at Fiorini, but this refers only to works in their collection. Details of Moore works cast at the Art Bronze Foundry Gaskin's, can be found on the National Portrait Gallery webpage resource 'British Bronze Sculpture Founders and Plaster Figure Makers: 1800-1980', available at: $\quad$ https://www.npg.org.uk/research/programmes/british-bronze-founders-and-plasterfigure-makers-1800-1980-1/british-bronze-founders-and-plaster-figure-makers-1800-1980-a (accessed 04 August 2018). Neither Fiorini nor Gaskin's list the lead Reclining Figure in its online records.

${ }^{10}$ Meadows had interviews with Judith Collins (09 December 1984), Artists' Lives Project interviewer Tamsyn Woollcombe (3 Nov-15 Dec 1992) and Julie Summers with the Henry Moore Foundation (12 May 1994). See Judith Collins, 'Henry Moore: Reclining Figure 1939' The Tate Gallery 1984-86: Illustrated Catalogue of Acquisitions Including Supplement to Catalogue of Acquisitions 1982-84, (London 1988) and British Library, 'National Life Stories, Artists' Lives - Bernard Meadows'. (Interviewed by Woollcombe), C466/08/13/01-12 (1992), 
can be found in the selection of works and accompanying narratives generated for the Henry Moore Foundation's 1998 publication Celebrating Henry Moore: Works from the Collection of the Henry Moore Foundation. He discusses one of the many lead string pieces (Stringed Figure, 1938$)^{11}$ made during his time at Burcoft with Moore, and explains:

[...] all castings were made by the lost wax process, which meant that for every cast Moore had to make an individual wax model, or alternatively a plaster mould from which another copy of the original could be taken in wax. Because this was a long and labour-intensive process no editions were made at this time - it was only by the early 1940s that Moore began to have bronze editions made by commercial foundries. ${ }^{12}$

As Meadows suggests Moore's later and more prolific engagements with bronze was the result of being able to recast and/or scale up the lead pieces into different editions with the use of commercial resources. This involved making a mould directly from the lead versions. Whereas the later productions were part of an expansion into a larger portfolio, perhaps

\section{https://sounds.bl.uk/related-content/TRANSCRIPTS/021T-C0466X0013XX-ZZZZA0.pdf}

(accessed 05 August 2018). My thanks to the Henry Moore Foundation for providing access to the Summers interview.

${ }^{11}$ Moore became preoccupied with making string figures as a result of his fascination and interest in geometric mathematical models at the Science Museum. For an account of the geometrical development of the string figures, see Alice Correia, 'Stringed Figure 1938. Cast 1960 by Henry Moore OM, CH', catalogue entry, January 2013, in Henry Moore: Sculptural Process and Public Identity. Tate Research Publication, 2015, available at: https://www.tate.org.uk/art/research-publications/henry-moore/henry-moore-om-chstringed-figure-r1146217. Also see the exhibition details for The Royal Society, Intersections: Henry Moore and Stringed Surfaces (4 April 2012-20 June 2012).

${ }^{12}$ Bernard Meadows' commentary on Stringed Figure, 1938 [LH186e], lead and string. Height $17.1 \mathrm{~cm}$. In. Celebrating Henry Moore: Works from the Collection of the Henry Moore Foundation, (eds.) Henry Moore, Julian Andrews, Henry Moore Foundation. Selected by David Mitchinson. (London: University of Chicago Press/Henry Moore Foundation, 1998), 170. 
driven by popular demand, one can imagine how materially focused and engaged this early experimentation actually was. Lead seemed to demand a labour intensive and hands-on process, not least because of its malleable character. Both Moore and Meadows developed a relationship with lead and its changeable states; from its low melting point, to its flexibility for realising thinner and more open form-states, and of course, in surface treatments which produced shiny and reflective effects. This was a process that began with drawing, moved into modelling, on into the lost-wax casting process, and through to the sometimes difficult and time-consuming surface finishes. Such treatments, as they were to discover, did not last long. There seemed to be a finitude to lead that required constant re-attention. For example, on the treatment of the lead cast, Meadows describes how the desired effect of a surface, 'much like polished silver', required the use of carpenter's tools and wood-carving tools (all too ready-to-hand at Burcroft) and 'soon found out that carborundum dust became embedded in the surface of the cast, preventing it from taking a good polish' ${ }^{13}$ After much testing, they discovered sharkskin to treat the surface.

The motivations for working with lead were, according to Kenneth Clark, merely an economic necessity. In an article entitled 'Henry Moore's Metal Sculptures', published in the Magazine of Art in 1951, he suggests that the works produced in 1938 'were lead not because he [Moore] had any particular preference for this material, but simply because it was cheap and could be cast in the home. At that date, Moore could not afford to have a figure cast in bronze in the very faint hope that someone would buy it'. ${ }^{14}$ But, as Meadows explains, lead is 'a seductive medium', and regardless of any financial reasons, working with this material so

\footnotetext{
${ }^{13}$ Meadows, Celebrating Henry Moore, 170.

${ }^{14}$ Kenneth Clark, 'Henry Moore's Metal Sculpture', Magazine of Art, May 1951, 171-174.
} 
intently and intimately, generated new complex shapes and forms in Moore's corpus. Lead and reinforced concrete are often perceived as the poor cousins to the diverse characteristics of stone or the fixed and somewhat elevated status of bronze. ${ }^{15}$ In the early and informative years as a sculptor, particularly with respect to experiments with different materials, and especially at Burcroft in collaboration with Meadows, Moore was able to really put his ideas about 'truth-to-materials' to the test. For example, in his 1934 'Statement for Unit One', included in Herbert Read's publication Unit One: the Modern Movement in English Painting, Sculpture and Architecture, to accompany the group's one and only exhibition at the Mayor Gallery in Cork Street, Moore writes: 'Every material has its own individual qualities. It is only when the sculptor works direct, when there is an active relationship with his material, that the material can take its part in the shaping of an idea'. ${ }^{16}$ This principle is usually associated with stone (the Unit One statement is preoccupied with carving processes), and when considered in relation to the material character of lead, we perhaps encounter something slightly more complicated, uneasy even. Lead does not allow the sculptor to follow flows and grooves, as with wood, or to track fault lines, as in a block of stone. Whereas carving is a deductive process, working with the biomorphic qualities of solid aggregate, thus ingratiating the tactile and haptic exchanges between hand and material, casting in lead is an alchemical process, where the journey from liquid to solid, requires form-making processes that are phase-driven. Each step in the process can radically disrupt the final outcomes: from the creation of the wax or plaster model, to the casing of the mould, to the liquefying of lead and

\footnotetext{
${ }^{15}$ See Anne Wagner's account in particular of the transformative effect a shift in material use has on the general symbolic, aesthetic and cultural reception of Moore's identity as a sculptor. Anne Middleton Wagner. Mother Stone: The Vitality of Modern British Sculpture. (New Haven, CT: Yale University Press, 2005).

${ }^{16}$ Henry Moore, 'Statement for Unity One' in Unit One, 29-30.
} 
its propensity to explode, through to the treatment of the surface of the solid form (the toxic emissions released by dust particles are particularly intense). Furthermore, after all these stages and treatments, the outcomes are still temporary. The stirrings of change begin with lead's exposure to air. Grey surfaces become tarnished. Forms become brittle. The fragility of lead generates transitory sculptural shapes. Its malleable character thus incorporates elements of fragility and toxicity, and with it, active problem solving to try to negotiate its unpredictable nature.

In the recollections provided by both Moore and Meadows, lead demanded a work ethic which produced constant dialogue and active problem-solving. Burcroft was a testing ground and lead provided the conditions of creative possibility for intense experimentation. And yet, despite the creative conditions afforded by the material, lead was still a rather difficult relationship to articulate, especially through the underlying principles of 'truth-tomaterials'. For example, in 1973, in an interview with Donald Carroll, Moore reflects on his own naivety towards the malleability and softness of lead as he encountered it in the 1930s, including his lack of knowledge about the techniques used to harden the material with other alloys. He explains:

We constructed our own kiln, and they [the models] were all cast in lead. I didn't know about lead - I didn't know that you could put a little antinomy with and make it hard - so since then all the leads have been damaged. And they come back to me to be repaired, or to be salvaged - because in some cases if you drop a lead on the floor, on 
a hard floor, it will just collapse, whereas bronze is indestructible. So to save the idea, I re-cast them into bronze [...]. ${ }^{17}$

Meadows elaborates on the use of lead materials in art schools during this period. More often than not, the supply of compo-piping meant that lead had already been galvanised and was thus softer than standard lead piping. Compo-pipes were used for the making of armatures for life modelling classes. As he explains in an interview with Julie Summers in 1994: 'It's bendable and that's the difference between compo-piping and lead piping. Lead piping would never be as flexible as that. The problem is really what makes the compo-piping bendable is impurities, it is something that they add to it to make to more bendable' ${ }^{18}$ The long term deterioration brought on by the impurities of the lead materials used, particularly with regard to the 'blooming and bubbling in the surface' of the casts, meant that the works of the late 1930s, are says Meadows, 'in a pretty deplorable state and there's nothing you can do about it'. ${ }^{19}$ Moore's own recollections in 1973 also recognise the error which in turn reinforced his need to devise ways to keep the ideas alive. He had no choice but to re-situate bronze as the material for sculptural longevity, and to perhaps, reluctantly break ties with lead's complex and unpredictable character.

\section{Exhibition Contexts}

Moore's Reclining Figure of 1931 not only served as the springboard into his later string pieces, produced in great quantity from 1937 onwards, and which featured in a solo show at

\footnotetext{
${ }^{17}$ Henry Moore, In. Alan Wilkinson (ed.) Henry Moore: Writings and Conversations, Berkley, Los Angeles: University of California Press, 2002, 235.

${ }^{18}$ Meadows interview with Julie Summers, 12 May 1994.

${ }^{19}$ Meadows interview with Julie Summers, 12 May 1994.
} 
the Leicester Galleries in 1940, it also travelled from London to the United States to be situated in two very different takes on Surrealism in 1936, the year Moore and Meadows start to work with each other. The contexts of these two shows encapsulate the reception of Reclining Figure, including its ability to act as a conductor between two different avant-gardist perspectives. It is with this piece that something is revealed about the contexts within which Moore's ideas about sculpture were situated in the 1930s, including the materiality of lead and its voice in these curatorial spaces.

Moore's principal British dealer was the Leicester Galleries. His second solo show took place in $1931,{ }^{20}$ with further exhibitions in 1933, 1936 and $1940 .{ }^{21}$ In 1934 he had already featured in Unit One, at the Mayor Gallery, London, and the first monograph on Moore had been written by Herbert Read and published by the Zwemmer Gallery. ${ }^{22}$ Moore's network

${ }^{20}$ Moore's first solo show was at the Warren Gallery, London in January in 1928 . This landmark exhibition caused some controversy leading to Moore's resignation from the Royal College of Art. For an account of Moore's teaching career, see Rebecca Wade, 'Learning from Moore between the Wars: Henry Moore as a Teacher at the Royal College of Art and Chelsea School of Art: 1924-39, in Henry Moore: Sculptural Process and Public Identity, Tate Research Publication, 2015, available at: https://www.tate.org.uk/art/research-publications/henrymoore/rebecca-wade-learning-from-moore-between-the-wars-henry-moore-as-a-teacherat-the-royal-r1151310 (accessed 21 August 2018).

${ }^{21}$ The gallery was known for representing European artists, since the First World War, with solo shows of Matisse, Maillol, Van Gogh, Epstein, Gaugin, Gaudier-Breszka and Picasso. For a detailed account of the history of sculpture shows at the Leicester Galleries during the decade of the 1930s, see Evelyn Sibler, 'The Leicester Galleries and the Promotion of Modernist Sculpture in London, 1902-1975' Sculpture Journal, Vol.21, Issue 2, 131-144. For a detailed list of exhibitions, see Ernest Brown \& Phillips Ltd., 'The Leicester Galleries. An index of 1422 catalogues of exhibitions of European Modern Art and $20^{\text {th }}$ Century British Art, held between 1902 and 1977', http://www.ernestbrownandphillips.Itd.uk/ HTML/LG\%20Catalogues/LG_Catalogues Date Order.html (accessed 21 August 2018).

${ }^{22}$ Herbert Read, Henry Moore, Sculptor. An Appreciation. (London: A. Zwemmer, 1934). 
was expanding, not only with visits to studios in Paris to meet artists such as Giacometti, Arp and Miro, but also in the social circles of Hampstead, with Ben Nicholson, Barbara Hepworth and Naum Gabo, with whom he was actively involved in later projects such as the 1937 Circle: International Survey of Constructive Art. ${ }^{23}$ The short period of time between 1936 and 1938 saw Moore move freely between different avant-gardist developments, and forming his own take on some of the current preoccupations of the time, most notably his engagements with both abstract and surrealist practices. In 1936 Moore had work in the following international exhibitions (in chronological order): in March, the wood carving Two Forms (LH153, 1934) featured in Barr's Cubism and Abstract Art (March 2- April 19), to be later purchased that year by $\mathrm{MOMA}^{24}$; in June, the lead cast Reclining Figure (LH101, 1931) appeared in The International Surrealist Exhibition at the New Burlington Galleries, and in December, Reclining Figure (LH101, 1931) was displayed in Barr's Fantastic Art, Dada, Surrealism at MOMA. In addition to these, Moore had a solo show at the Leicester Galleries in November of that year. $^{25}$

\footnotetext{
${ }^{23}$ In 1935, Gabo, Marcel Breuer and Moholy-Nagy came to London.

${ }^{24}$ Two Forms had also appeared in the 1935 exhibition Artists Against Fascism \& War, 28 Soho Square, London, between Nov 13-27.

${ }^{25}$ Moore exhibited work in other shows during this period, but those cited are the most relevant to this chapter's account of lead. Access to the catalogues produced by Barr can be found in digital forms on the MOMA website. See Museum of Modern Art (N.Y.), Cubism and Abstract Art [catalogue] (New York: The Museum of Modern Art, 1936), available at: https://www.moma.org/calendar/exhibitions/2748

and Museum of Modern Art (N.Y.) Fantastic Art, Dada, Surrealism [catalogue] (New York: The Museum of Modern Art, 1936), available at: https://www.moma.org/calendar/exhibitions/2823 For an account of the directorship of Alfred H. Barr, see in particular, Irving Sander and Amy Newman (eds.) Defining Modern Art: Selected Writings of Alfred H. Barr (New York: Harry N. Abrahams Inc, 1986).
} 
As Director of MOMA, Barr regularly visited Europe, to meet art dealers, visit studios, galleries and museums. This network played a key role in his securing of works for his curatorial projects, as well as facilitating long term acquisitions. Barr met Moore at his studio, in 1927, through a curatorial contact at the Victoria and Albert Museum, and selected Two Forms for the Cubism and Abstract Art show. This work, along with eighteen other pieces, were stopped at US customs, for not being deemed 'art' under a ruling, according to Barr, 'which requires that sculpture must represent an animal or human form'. The pieces were perceived as too abstract and not 'imitations of natural objects, chiefly of the human form in their true proportion of length, breadth, and thickness'. ${ }^{26}$ In the catalogue to the show Barr makes explicit reference to US censorship, by referring to customs as 'philistines with political power' and listing all the works that had been retained at the moment of the catalogue's publication into print. ${ }^{27}$ The complex and difficult irony of this customs embargo lies in the underlying motivations of Barr, who was actively developing a curatorial programme which would help to educate the public about art and its aesthetic histories. His ambitions, against those ideologies familiar to the cultural censorship policies under Fascism and Soviet Socialism in Europe, with its emphasis on content driven political propaganda, were channelled through a pluralist vision for modern art, and in his directorial role at MOMA, he sought to generate key exhibitions which would historically and aesthetically re-situate the avant-garde. For example, Barr located precedents for the modernist innovations of the early

\footnotetext{
${ }^{26}$ See Barr, Cubism and Abstract Art [catalogue], fn.1, 18 and 'Cubism and Abstract Art: press clippings, 1936', https://www.moma.org/research-and-learning/archives/archiveshighlights-03-1936. Of the works retained, and which were only released after MOMA paid an importation tariff under the classification of 'building materials', included Boccioni's Development of a Bottle in Space (1912) and Unique Forms of Continuity in Space (1913), Miro's Relief Construction (1930) and Giacometti's Head-Scape (1932).

${ }^{27}$ Barr, Cubism and Abstract Art, 18
} 
twentieth century (which the Nazis were all to ready to veto) in the formalist styles of impressionism and post-impressionism, and, in nineteenth-century art history and its readings of the stylistic traces of the Renaissance and Baroque art. In the catalogue essay for Cubism and Abstract Art Barr refers to Moore's Two Forms, in relation to the influences of Arp and Picasso; to organic forms, varied materials, textures and colours. As representatives of two extremes on an abstract spectrum, Barr also situates Moore and Nicholson at either ends, from the 'non-geometrical (or 'biomorphic') to the 'geometrical'. ${ }^{28}$ The ancestral roots tracked through his chart for Cubism and Abstract Art was a provocative and challenging counter-formation to the curatorial strategies and mechanisms deployed by the Nazis, with for example, the infamous 1937 Degenerate Art installation; an intended shock trigger to exemplify the horrors of modern art in contrast to the classical ideals perpetuated in The Great German Exhibition of 1937-39. ${ }^{29}$

A matter of months later, Reclining Figure would also make a journey to New York, to be exhibited in Barr's Fantastic Art, Dada, Surrealism show. But not before its remarkable appearance in June at the New Burlington Galleries for The International Surrealist Exhibition. This was a mammoth project, featuring over 390 works, 68 artists, and representing 14 countries. Moore was involved in the organising committee in England, alongside Herbert

\footnotetext{
${ }^{28}$ Barr, Cubism and Abstract Art, 200. To note, this is prior to Moore's stringed figure series which he produced in the late 1930s. The constructivist turn to geometrical figures was certainly informed by Circle and Moore's collaborations with Nicholson, Hepworth and Gabo. ${ }^{29}$ For an insightful overview of this exhibition, including its art historical and curatorial underpinnings, see Susan Noyes Platt, 'Modernism, Formalism, and Politics: the "Cubism and Abstract Art" exhibition of 1936 at the Museum of Modern Art'. Art Journal, Vol. 47, Revising Cubism (Winter, 1988), 284-295, https://www.jstor.org/stable/776979. My thanks to Francesco Ventrella for introducing me to the underlying aesthetic, historical and morphological ambitions of Barr's projects.
} 
Read, Paul Nash, and Roland Penrose as Honorary Treasurer. ${ }^{30}$ In addition to Reclining Figure Moore exhibited works that had featured in Cubism and Abstract Art, alongside new works and preparatory drawings. The pieces exhibited included: including Reclining Figure (carved reinforced concrete, LH134, 1933), Figure (Travertine marble, LH137, 1934) and Carving (Blue Ancaster stone, LH139, 1933-4).$^{31}$ Breton's rehanging situated Reclining Figure in the vicinity of Richard Oelze's Daily Torments (1934), Miro's The Tilled Field (1923-24), Bellmer's La poupée (The Doll, 1936) and Dali's Dream (1931). His politically charged preface to the exhibition catalogue called for 'the abolition of the ego in the id' and to break down the barriers of civilisation which have constrained our ability to re-imagine the 'reality of the external world'. ${ }^{32}$

According to Christina Lichtenstern, these selections are examples that engage with the processes of creating 'biomorphic' forms. Exposed rods from the lead armature in Reclining Figure are, she explains, 'space-conductors and simultaneously brace the swelling anatomical sections, linearly, one with the other'. ${ }^{33}$ These 'space-conductors' negotiate what Moore would later articulate in 'The Sculptor Speaks' in 1937 as his unique relation to abstraction and surrealism. As Lichtenstern suggests, Moore's contribution to the exhibition

\footnotetext{
${ }^{30}$ Other members of the committee included Hugh Sykes Davies, David Gascoyne, Humphrey Jennings, McKnight Kauffer, Rupert Lee.

${ }^{31}$ This list is identified by Meadows in his interview with Julie Summers in 1994 (Henry Moore Foundation).

${ }^{32}$ See André Breton, 'Preface', 7 In addition to Read's edited book on surrealism, published in 1936, he also wrote an introduction to the exhibition catalogue for The International Surrealist Exhibition (London: New Burlington Galleries, 1936).

${ }^{33}$ Christina Lichtenstein, 'Henry Moore and Surrealism', The Burlington Magazine, Vol. 123, No.944. (Nov. 1981), 647. Also see Steven A. Nash, 'Moore and Surrealism Reconsidered' In. Henry Moore Sculpting the $20^{\text {th }}$ Century, (ed.) Dorothy Kosinski, Dallas Museum of Art (New Haven and London: Yale University of Press, 2001), 43-51.
} 
'on the one hand demonstrates his understanding of biomorphous form - developed further via Picasso, Arp, Giacometti and Lipchitz, and on the other hand his conception of an 'emotional space' (emotionaler Raum) which, deduced from the material, subsequently adopts the imaginary compactness of a "form"'. ${ }^{34}$ And in Kenneth Clark's reflections on Reclining Figure in his article on Moore's metal sculptures, he is particularly drawn to its 'descriptive references to parts of the human body' which appears to render it 'less human [...] like some terrifying insect' ${ }^{35}$ An analogy perhaps for the anxious state of the human condition.

Reclining Figure had already found an identity in the London show when it travelled to feature in Fantastic Art. Barr had visited the exhibition, as well as taking in the Surrealist Exhibition of the Object at the Galerie Charles Ratton in Paris in May 1936. According to Tessel M. Baudin, when Barr met Breton and Paul Eluard he began to discuss possible collaborations for his proposed show at MOMA. But their disagreements about the curation - its organisation and presentation - led to Breton and Eluard withdrawing their participation in the summer of $1936 .{ }^{36}$ Barr's encounter with Reclining Figure on display at The International

\footnotetext{
34 Lichtenstein, 'Moore and Surrealism', 647. For an account of Moore's interest in the morphologies of the nature and its materials (the physiology of the human body included), see Edward Julier, 'Life Forms: Henry Moore, Morphology and Biologism in the Interwar Years', in Henry Moore: Sculptural Process and Public Identity, Tate Research Publication, 2015, https://www.tate.org.uk/art/research-publications/henry-moore/edward-juler-lifeforms-henry-moore-morphology-and-biologism-in-the-interwar-years-r1151314 (accessed 21 August 2018).

${ }^{35}$ Clark, 'Henry Moore's Metal Sculpture', 171.

${ }^{36}$ Baudin has a convincing argument which suggests that Breton's preoccupation with the marvellous was radically disturbed by Barr's ideas on the 'fantastical', so much so, that Breton incorporates these ideas into his early speeches for The International Surrealist Exhibition. See Tessel M. Baudin, 'Fantastic Art, Barr, surrealism' Journal of Art Historiography, No.17 (Dec 2017), 1-23, https://arthistoriography.files.wordpress.com/2017/11/bauduin.pdf
} 
Surrealist Exhibition, and within the curated scene of the imaginary dream-like states Breton had associated it with, may certainly have served as an influential reading. In the catalogue, there is no mention of Moore by Barr, as he does in the Cubism and Abstract Art show, nor is there a mention in the historical and informative essays provided by Georges Hugnet. Instead, there is a photographic plate of Reclining Figure (no.445) nestled between plates no.435, no. 444 and no.450. Plate no.435 and no.444 features Miro's Relief (1930) (lent by Breton), and one of Miro's gouaches (1935-6), and plate no.450, includes, for the second time, Oelze's Daily Torments (1934). Aside from the chronological ordering of this sequence, there is much mirroring of the context within which Reclining Figure appeared at the New Burlington Galleries in London. But this is also telling. The 'biomorphous form' and 'emotional space' of the lead work still carries into the curatorial arena of Fantastic Art. The modes of display which allowed Moore, Miro and Oelze to be physically spatialized and thus realised together, is also the contribution Reclining Figure makes as a form which has embedded within it, the materiality of the idea. Reclining Figure served as a visible and spatial counter-formation to the disturbing forces of new aesthetic and fascistic ideologies. Lead makes the meaningmaking capacity of this sculpture possible. The armature rods, adapted and embedded into the structure of a human torso, is of the material itself. As it bears the traces of its raw 'piping' state we are exposed to lead as an emotional metal, a carrier of intensities; a condition for the sculptural production of form-space. The torso of Reclining Figure is thus protective container for 'emotional space' and external barrier to the psychic interiorities and intensities that reside within. It is a ribcage with a heart. Moreover, its anatomical rods, as markers of the materiality of lead, are also vein conductors of and for the various ebbs and flows of energy. Energy is the force of inevitable transformation and lead is the carrier of this change. It is more than likely that Moore understood this particular material characteristic. And 
perhaps as an homage to lead, Moore's later 1939-40 piece Three Points seems to honour the material's ability to conduct forces (of the spatial and the psychic kinds). The suspended space generated by the structural formation of three lead points is a psychic and imaginative tension. We almost see the sparks fly. As a conductor/carrier of waves of energy lead is constantly transformed by the elemental and atmospheric forces that run through it. Its malleability is its fragility.

\section{Conclusion}

Lead, in all of its vulnerability and impermanence, tells a story about material failure, the temporalities of matter and coming to terms with loss. Moore's sculptural thinking with lead in the inter-war period, as an active, vibrant and exciting phase of experimentation, is also an encounter with the finitude of materials. The early stirrings of the Helmet Head series of the 1950s takes place in 1939-40, with two interior figures and two helmets, one in lead and one in bronze. ${ }^{37}$ According to Patrick Elliott in Another World: Dali, Magritte, Miro and the Surrealists, a publication by The Scottish National Gallery of Modern Art on its Dada and Surrealist collection, the helmet evolved out of several themes. ${ }^{38}$ On the one hand, the helmet can be seen as a sheltering armour protecting the softer more delicate form inside. An archetypal womb scenario. On the other hand, the helmet also serves as a cage to imprison and entrap; a possible reference point to Moore's lithographic print of a Spanish republican

\footnotetext{
${ }^{37}$ See the Henry Moore Foundation catalogue for these works: The Helmet (LH212, cast 1, 1939-40), available at http://catalogue.henry-moore.org/objects/24534/the-helmet, and Interior Figure (LH212a, cast 1), available at http://catalogue.henrymoore.org/objects/17611/interior-figure?ctx=749f602b-ce54-4fc4-a13a652ec5ff5d01\&idx=0 and The Helmet (LH212, cast 2, 1939-40), available at http://catalogue.henry-moore.org/objects/16846/the-helmet/related/1022 ${ }^{38}$ See Patrick Elliott, Another World: Dali, Magritte, Miro and the Surrealists (Edinburgh: National Galleries of Scotland, 2010).
} 
prisoner, first produced in 1939, and to earlier studies of Greek helmets he made during his visits to the Wallace Collection as a student in the $1920 \mathrm{~s}^{39}$ Moore's studies of the metalwork of armoury extends to the formation of The Helmet in 1939-40. ${ }^{40}$

The later Helmet Head series of the 1950s, is much more considered and representative of the negative and sinister connotations of imprisonment and capture. ${ }^{41}$ This is a period informed by Moore's own experience as a war artist, which had certainly transformed his relationship to sculptural practice. The earlier lead prototype seems more disturbing. As a protective shield for the interior figure, there is speculation on the magnitude of what is to come, both for lead as a material and for European modernism. It is also the last piece made by Moore before the bombing of his Hamsptead flat. Lead was ceasing to be in ready supply. As a metal resource for the manufacturing of ammunition bullets for artillery warfare it is a startlingly extreme and somewhat saddening turn in Moore's relationship to lead. In this sense the very materiality of The Helmet betrays its function as a protective shield for the interior figure inside.

39 See Henry Moore, Spanish Prisoner (Lithograph, CGM, 1939), available at: http://catalogue.henry-moore.org/objects/8332 This is also reflected in Moore's public stand against the atrocities of the Spanish Civil War, through membership with organisations such as the Artists International Association (AIA) (which he joined in 1933, the same year he meets Giacometti, Zadkine and Lipchitz in Paris). Notwithstanding, the famous studio visit to see Picasso and an unfinished Guernica.

${ }^{40}$ See also Andrew Causey for an account of Moore's investigations into form and body as 'envelopment' in the Helmet Head series, including the 1939-40 version and its underlying anxiety about the threat of war. Andrew Causey, The Drawings of Henry Moore. (London: Lund Humphries, 2010).

${ }^{41}$ For an account of the series, see in particular, Alice Correia, 'Helmet Head No. 1 1950, cast 1960 by Henry Moore OM, CH' catalogue entry. November 2013, in Henry Moore: Sculptural Process and Public Identity. Tate Research Publication, 2015, https://www.tate.org.uk/art/research-publications/henry-moore/henry-moore-om-chhelmet-head-no1-r1149255 (accessed 23 August 2018). The Henry Moore Foundation exhibition of the helmet heads is forthcoming. 
In June and July of 1940 , as part of the Surrealism Today exhibition at the Zwemmer Gallery, London, Moore exhibits the lead version of The Helmet (1939-40) for the first time, alongside two reclining figures, one of which was the lead piece of 1931 , whose life as a travelling object had crossed continents to appear in ground-breaking international shows on modernist and avant-gardist thinking. The beginning and potential end of the cycle of lead was in articulation in Surrealism Today. It was through this platform that Reclining Figure (1931) was purchased by a Mr and Mrs Zimmerman, located in New York, and the lead version of The Helmet was purchased by Roland Penrose, to later be bought by the National Galleries of Scotland in $1992 .^{42}$ So, whilst The Helmet stayed behind in Europe, under the watchful eye of the surrealist Penrose, Reclining Figure travelled to the United States again, this time, into a private collection. Frederick Zimmerman was an American double bassist who played in the New York Philharmonic Orchestra, between 1930 and 1966.

The materiality of lead is instrumental to understanding the sculptural thinking embodied in Moore's early experiments with casting. His appearance on the stage of European modernism, and as a defender of it, is at the same time, a marker of loss in terms of lead's extinction from Moore's portfolio. Not only were the ideas and practices of the European avant-garde subject to geographical displacement and dispersal across the globe, and with this, the promise of the development of new formations in a cultural climate that had been exposed to the catastrophes of war, it was simultaneously, a time of mourning the loss of what once was. Lead's fragility as a material meant that Moore's journey towards the monumentality of bronze, was a necessary and logical step in a post-production process after

\footnotetext{
${ }^{42}$ With assistance from the National Heritage Memorial Fund, the Art Fund (Scottish Fund) and the Henry Moore Foundation.
} 
the Second World War. Perhaps lead had been teaching Moore about the forces of inevitable change all along, and, as a result of the casting processes he went through in the 1930s, developed a closer and more intimate relationship to the changing states of matter. The choice to turn to bronze, as a creative and cathartic process, is a way to supplement loss through the creation of new material forms. This is how we keep the ideas alive.

\section{Bibliography}

Bailey, Rowan. 'Concrete Thinking for Sculpture' parallax, 21:3, 241-250. https://www.tandfonline.com/doi/full/10.1080/13534645.2015.1058884

British Library. 'National Life Stories, Artists' Lives - Bernard Meadows'. (Interviewed by Tamsyn Woollcombe), C466/08/13/01-12 (1992), https://sounds.bl.uk/relatedcontent/TRANSCRIPTS/021T-C0466X0013XX-ZZZZA0.pdf (accessed 05 August 2018).

Baudin, Tessel M. 'Fantastic Art, Barr, surrealism' Journal of Art Historiography, No.17 (Dec 2017), 1-23, https://arthistoriography.files.wordpress.com/2017/11/bauduin.pdf

Clark, Kenneth. 'Henry Moore’s Metal Sculpture', Magazine of Art, May 1951, 171-174.

Causey, Andrew. The Drawings of Henry Moore. (London: Lund Humphries, 2010).

Collins, Judith. 'Henry Moore: Reclining Figure 1939' The Tate Gallery 1984-86: Illustrated Catalogue of Acquisitions Including Supplement to Catalogue of Acquisitions 1982-84, London 1988.

Correia, Alice. 'Stringed Figure 1938. Cast 1960 by Henry Moore OM, CH', catalogue entry, January 2013, in Henry Moore: Sculptural Process and Public Identity. Tate Research Publication, 2015, https://www.tate.org.uk/art/researchpublications/henry-moore/henry-moore-om-ch-stringed-figure-r1146217 (accessed 05 August 2018).

Alice Correia, 'Helmet Head No. 1 1950, cast 1960 by Henry Moore OM, CH' catalogue entry. November 2013, in Henry Moore: Sculptural Process and Public Identity. Tate Research Publication, 2015, https://www.tate.org.uk/art/research-publications/henrymoore/henry-moore-om-ch-helmet-head-no1-r1149255 (accessed 23 August 2018).

Correia, Alice. 'Recumbent Figure 1938 by Henry Moore OM, $\mathrm{CH}^{\prime}$, catalogue entry. January 2013 In. Henry Moore: Sculptural Process and Public Identity. Tate Research Publication, 2015, https://www.tate.org.uk/art/research-publications/henrymoore/henry-moore-om-ch-recumbent-figure-r1147451 (accessed 21 August 2018). 
Ernest Brown \& Phillips Ltd., 'The Leicester Galleries. An index of 1422 catalogues of exhibitions of European Modern Art and 20 $0^{\text {th }}$ Century British Art, held between 1902 and1977'http://www.ernestbrownandphillips.Itd.uk/ HTML/LG\%20Catalogues/LG_C atalogues Date Order.html (accessed 21 August 2018).

Elliott, Patrick. Another World: Dali, Magritte, Miro and the Surrealists. Edinburgh: National Galleries of Scotland, 2010.

Henry Moore Foundation online catalogue of Henry Moore's works from 1914 to 1949:

Henry Moore Foundation. 'Interview with Bernard Meadows, 12 May 1994', conducted with Julie Summers.

Julier, Edward. 'Life Forms: Henry Moore, Morphology and Biologism in the Interwar Years' In. Henry Moore: Sculptural Process and Public Identity, Tate Research Publication, 2015, $\quad$ https://www.tate.org.uk/art/research-publications/henry-moore/edwardjuler-life-forms-henry-moore-morphology-and-biologism-in-the-interwar-yearsr1151314 (accessed 21 August 2018).

Lichtenstein, Christina. 'Henry Moore and Surrealism', The Burlington Magazine, Vol. 123, for a special issue Devoted to Twentieth Century Art, No.944. 647, Nov. 1981, 644658.

Meadows, Bernard. 'Commentary on Stringed Figure, 1938 [LH186e], lead and string. Height $17.1 \mathrm{~cm}$ '. In. Celebrating Henry Moore: Works from the Collection of the Henry Moore Foundation, (eds.) Henry Moore, Julian Andrews, Henry Moore Foundation. Selected by David Mitchinson. London: University of Chicago Press/Henry Moore Foundation, 1998.

Moore, Henry. 'Statement for Unit One' in Read, H. (ed.) Unit One: The Modern Movement in English Architecture, Painting and Sculpture. London: Casel \& Co, 1934, 29-30.

Moore, Henry. 'The Sculptor Speaks' In. Henry Moore, Henry Moore: On Being as Sculptor London: Tate Publishing, 2010.

Morgan, Lyndsey and van der Molen, Rozemari. 'Henry Moore's Approach to Bronze' In. Henry Moore; Sculptural Process and Public Identity. Tate Research Publication, 2015. https://www.tate.org.uk/art/research-publications/henry-moore/lyndsey-morganand-rozemarijn-van-der-molen-henry-moores-approach-to-bronze-r1151468 (accessed 04 August 2018)

Museum of Modern Art (N.Y.), Cubism and Abstract Art [catalogue] (New York: The Museum of Modern Art, 1936), https://www.moma.org/calendar/exhibitions/2748 (accessed 05 August 2018).

Museum of Modern Art (N.Y.) Fantastic Art, Dada, Surrealism [catalogue] (New York: The 
Museum of Modern Art, 1936), https://www.moma.org/calendar/exhibitions/2823 (accessed 05 August 2018).

Museum of Modern Art (N. Y.), 'Cubism and Abstract Art: press clippings, 1936', https://www.moma.org/research-and-learning/archives/archives-highlights-03-1936 (accessed 05 August 2018).

Nash, Steven A. 'Moore and Surrealism Reconsidered' In. Henry Moore Sculpting the $20^{\text {th }}$ Century, (ed.) Dorothy Kosinski, Dallas Museum of Art (New Haven and London: Yale University of Press, 2001), 43-51.

National Portrait Gallery. 'British Bronze Sculpture Founders and Plaster Figure Makers: 1800-1980'.: $\quad$ https://www.npg.org.uk/research/programmes/british-bronzefounders-and-plaster-figure-makers-1800-1980-1/british-bronze-founders-andplaster-figure-makers-1800-1980-a (accessed 04 August 2018).

Noyes Platt, Susan. 'Modernism, Formalism, and Politics: the "Cubism and Abstract Art" exhibition of 1936 at the Museum of Modern Art'. Art Journal, Vol. 47, Revising Cubism (Winter, 1988), 284-295. Available at https://www.jstor.org/stable/776979

Read, Herbert. Henry Moore; Sculptor: An Appreciation. London: Zwemmer, 1934.

Read, Herbert (ed.) Unit One: The Modern Movement in English Architecture, Painting and Sculpture. London: Casel \& Co, 1934.

Read Herbert. (ed.) Surrealism. London: Faber \& Faber, 1936.

The Royal Society, Intersections: Henry Moore and Stringed Surfaces, 4 April 2012-20 June, Science Museum's Mathematics Gallery and Royal Society's President Gallery at the Isaac Newton Institute for Mathematical Sciences, 2012.

Sander, Irving and Newman, Amy (eds.) Defining Modern Art: Selected Writings of Alfred $\mathrm{H}$. Barr (New York: Harry N. Abrahams Inc, 1986).

Sibler, Evelyn. 'The Leicester Galleries and the Promotion of Modernist Sculpture in London, 1902-1975' Sculpture Journal, Vol.21, Issue 2, 131-144. DOI: 10.3828/sj.2012.24

Wade, Rebecca. 'Learning from Moore between the Wars: Henry Moore as a Teacher at the Royal College of Art and Chelsea School of Art: 1924-39' In. Henry Moore: Sculptural Process and Public Identity, Tate Research Publication, 2015, https://www.tate.org.uk/art/research-publications/henry-moore/rebecca-wadelearning-from-moore-between-the-wars-henry-moore-as-a-teacher-at-the-royalr1151310 (accessed 21 August 2018)

Wagner, Anne Middleton. Mother Stone: The Vitality of Modern British Sculpture. New Haven, CT: Yale University Press, 2005. 
Wilkinson, Alan (ed.) Henry Moore: Writings and Conversations. Berkley, Los Angeles: University of California Press, 2002. 